\title{
Transposon Mutagenesis and Complementation of the Fructokinase Gene in Rhizobium leguminosarum biovar trifolii
}

\author{
By R. E. MCLAUGHLin ANd T. A. HUGHES* \\ Department of Microbiology, Clemson University, Clemson, South Carolina 29634-1909, USA
}

(Received 12 December 1988; revised 17 February 1989; accepted 23 April 1989)

\begin{abstract}
Transposon Tn5 was used to generate a fructokinase mutation in Rhizobium leguminosarum biovar trifolii BAL. The section of the genome containing Tn 5 was cloned into the EcoRI site of the vector pHC79 and isolated by direct selection on medium containing kanamycin and tetracycline. Total EcoRI digestion was used to obtain a single fragment containing Tn 5 and flanking DNA sequences. The flanking DNA was used as a probe to isolate an intact fructokinase gene from a pLAFRl cosmid clone bank of the parental strain. A cosmid showing homology to the probe was tri-parentally conjugated into the fructokinase-negative strain, complementing the mutation. The complemented mutant exhibited the wild-type phenotype, with an increase in fructokinase production presumably due to multiple copies of the gene.
\end{abstract}

\section{INTRODUCTION}

Little is known about the central pathways of carbohydrate metabolism in rhizobia. Carbohydrate supply is a major limiting factor in nitrogen fixation by the Rhizobium-legume symbiosis (Hardy, 1977; Pate, 1977). Much of the information available about the components of rhizobial pathways has been derived through the use of chemical mutagens. Although highly useful, chemical mutagens may often lead to confusing and conflicting results.

Using transposons to generate mutations eliminates many of the uncertainties associated with chemical mutagens. Many transposons, including $\operatorname{Tn} 5$, are very stable once inserted into the genome. This makes them particularly useful because they lead to single site mutations that are easily identified. The isolated segment of DNA can then be used as a specific probe to identify the functional gene from a genomic library of the parental strain (Chakravorty et al., 1982).

Metabolic mutations in Rhizobium have been generated by Tn 5 mutagenesis (Arwas et al., 1985; Duncan, 1981 ; Glenn et al., $1984 a, b$ ), but isolation and complementation of these genes have not previously been reported. In this communication we describe the generation of a fructokinase mutation in Rhizobium leguminosarum biovar trifolii BAL by Tn 5 mutagenesis, isolation of the gene, and complementation of the mutant strain. Fructokinase levels in the parental BAL strain, the mutant and the complemented mutant, were examined, as well as levels of other key metabolic enzymes.

\section{METHODS}

Bacterial strains and media. Rhizobium leguminosarum biovar trifolii BAL and mutant derivative strains were grown on yeast extract mannitol medium (YEM) (Vincent, 1970) or Rhizobium defined medium (RDM) containing $0.4 \%$ (w/v) carbohydrate (Ronson \& Primrose, 1979). BAL strains were maintained on YEM medium supplemented with the appropriate antibiotic (Table 1). Escherichia coli strains were grown and maintained on Luria-Bertani (LB) medium (Maniatis et al., 1982) supplemented with the appropriate antibiotic (Table 1). All cultures were incubated at $28^{\circ} \mathrm{C}$ and broth cultures were shaken at 200 r.p.m. in an orbital water bath. Rhizobium cultures were checked for phenotypic markers (antibiotic and carbohydrate) before and after each experiment. Growth on tryptic soy agar (TSA) was routinely examined as a check for contamination.

Abbreviations: LB, Luria-Bertani; RDM, rhizobium defined medium; YEM, yeast extract mannitol medium. 


\section{Table 1. Bacterial strains and plasmids}

Strain

\section{R. leguminosarum}

biovar trifolii

BAL

BAL 79

BAL C79

E. coli

HB101

Plasmids

pHC79

pLAFR1

pSUP1011

pLA72
Phenotype* or

genotype

Parental strain

Frk $^{-}$[ frk : :Tn5(Km $\left.\left.{ }^{\mathrm{r}}\right)\right]$

Frk $^{+}$[BAL 79(pLA72)(Tcr)]

$\mathrm{F}^{-}$hsdS20 recA ara pro $\mathrm{Str}^{\mathrm{r}}$

$\mathrm{Ap}^{\mathrm{r}} \mathrm{Tc}^{\mathrm{r}} \lambda \mathrm{cos}$

$\mathrm{Tc}^{\mathrm{r}}$ oriT $\lambda \cos$

$\mathrm{Cm}^{\mathrm{r}} \mathrm{Km}^{\mathrm{r}}:: \mathrm{Tn} 5$

$\mathrm{Tc}^{\mathrm{r}}$ frk $^{+}$
Reference or source
F. B. Dazzo $\dagger$

This report

This report

Maniatis et al. (1982)

Hohn \& Collins (1980)

Friedman et al. (1982)

Simon et al. (1983)

This report

* Phenotype symbols: Frk-/Frk+, fructokinase negative/positive; $\mathrm{Ap}^{\mathrm{r}}$ ampicillin resistance; $\mathrm{Cm}^{\mathrm{r}}$, $\mathrm{chloram}^{-}$ phenicol resistance; $\mathrm{Tc}^{\mathrm{r}}$, tetracycline resistance; $\mathrm{Km}^{\mathrm{r}}$, kanamycin resistance on $\mathrm{Tn} 5$; $\mathrm{Str}^{\mathrm{r}}$, $\operatorname{streptomycin}$ resistance.

† F. B. Dazzo, Michigan State University, East Lansing, MI 48824-1101, USA.

Generation and verification of Tn5 mutants. Tn 5 was introduced into the BAL strain using the Mob transfer system (Simon et al., 1983). After incubation for $24 \mathrm{~h}$, cells were washed from filters with $1 \mathrm{ml}$ of a $0.9 \%(\mathrm{w} / \mathrm{v})$ $\mathrm{NaCl}$ solution containing $0.01 \%(\mathrm{v} / \mathrm{v})$ Tween 20 , and were plated on YEM medium containing kanamycin $\left(150 \mu \mathrm{g} \mathrm{m}^{-1}\right)$ and streptomycin $\left(75 \mu \mathrm{g} \mathrm{ml}^{-1}\right)$ to select for $\operatorname{Tn} 5$ transconjugants. In addition to antibiotic markers, transposon integration was verified by Southern gel analysis (Southern, 1975) using the internal $B g l$ II fragment of Tn 5 as a probe. Probes for colony and Southern hybridizations were labelled with [ $\left.{ }^{32} \mathrm{P}\right] \mathrm{dCTP}$ using the Amersham nick translation kit. Hybridizations were done at $55^{\circ} \mathrm{C}$, without formamide, using the solutions and washes recommended by Wahl et al. (1981).

DNA isolation. Total DNA was isolated from BAL strains in the following manner. Overnight cultures grown in YEM broth were harvested and resuspended in $0.25 \mathrm{ml}$ alkaline solution I (Maniatis et al., 1982). SDS (10\%, w/v) was added to the cell suspension to a final concentration of $1 \%(\mathrm{v} / \mathrm{v})$ and heated at $65^{\circ} \mathrm{C}$ for $10 \mathrm{~min}$. The solution was extracted twice with an equal volume of Tris/EDTA buffer (TE; pH 7.6) (Maniatis et al., 1982), saturated with phenol/chloroform $(1: 1)$ and centrifuged for $10 \mathrm{~min}$ at approximately $14000 \mathrm{~g}$. DNA was precipitated from the aqueous phase by addition of 3 vols $95 \%(v / v)$ ethanol, at room temperature, and further purified by $\mathrm{CsCl}$ density centrifugation (Maniatis et al., 1982).

Cosmid vectors and clones were isolated from $E$. coli and BAL C79 using the alkaline extraction method (Birnboim \& Doly, 1979) and purified by two successive $\mathrm{CsCl}$ density gradients.

Cosmid cloning. Cosmid clone banks of BAL and BAL 79 were constructed as recommended by Maniatis et al. (1982). The first was constructed from EcoRI restriction endonuclease digested DNA isolated from BAL 79 and ligated into alkaline phosphatase treated vector pHC79. The packaged DNA was transfected into E. coli HB101 and plated on LB medium containing kanamycin $\left(50 \mu \mathrm{g} \mathrm{ml}^{-1}\right)$ and tetracycline $\left(25 \mu \mathrm{g} \mathrm{ml}^{-1}\right)$ for direct selection of cosmids containing Tn 5 inserts. A total of 1000 clones was obtained.

The second clone bank was similarly constructed from the parental strain using cosmid vector pLAFR1. Approximately 700 cosmid clones were selected on LB plus tetracycline $\left(25 \mu \mathrm{g} \mathrm{m}^{-1}\right)$ and replica plated to nitrocellulose discs for colony hybridization analysis.

Isolation and complementation of the fructokinase gene. A cosmid containing Tn 5 was subcloned to yield a single $E c o$ RI fragment, containing the insertionally inactivated fructokinase gene. This fragment was used to probe approximately 450 of the pLAFR1 cosmids by colony hybridization (Grunstein \& Hogness, 1975). One of the cosmids showing homology was designated pLA72 and conjugated into BAL 79 by tri-parental mating (Sutton et al., 1984). Transconjugants were selected on RDM-mannitol medium containing kanamycin $\left(150 \mu \mathrm{g} \mathrm{ml}^{-1}\right)$ and tetracycline $\left(25 \mu \mathrm{g} \mathrm{ml}^{-1}\right)$.

Cell-free extract preparation. Cultures for enzyme analysis were grown in $100 \mathrm{ml}$ of broth (YEM or RDM) and harvested during exponential phase by centrifugation at $6000 \mathrm{~g}$ for $10 \mathrm{~min}$. The cell pellet was washed once with $50 \mathrm{ml}$ of $0.05 \mathrm{M}$-sodium phosphate buffer ( $\mathrm{pH} \mathrm{7.2)} \mathrm{and} \mathrm{resuspended} \mathrm{in} 2 \mathrm{ml}$ of the same buffer containing $1 \mathrm{mM}$-dithiothreitol. Cells were then lysed by sonication on ice using the intermediate tip on a Fisher sonic dismembrator, model 300 , at $60 \%$ power for four $30 \mathrm{~s}$ bursts with intermittent $30 \mathrm{~s}$ cooling periods. Extracts were clarified by centrifugation at $20000 \mathrm{~g}$ for $30 \mathrm{~min}$ at $4{ }^{\circ} \mathrm{C}$. Cell free extracts prepared in this manner were used for all enzymic assays. 
Uptake of ${ }^{14} \mathrm{C}$-labelled mannitol. Cells grown in YEM broth were harvested and assayed for the ability to transport [1-14 C]mannitol (Sigma) as described by Ronson \& Primrose (1979).

Protein determination. Cell-free extracts from samples were analysed in duplicate for protein content using the dye-binding method (Bradford, 1976), using bovine serum albumin (fraction V, Sigma) as the standard.

Enzyme assays. Glucokinase (EC 2.7.1.2; ATP:D-glucose 6-phosphotransferase), and fructokinase (EC 2.7.1.4; ATP :D-fructose 6-phosphotransferase) activities were determined by following the reduction of $\mathrm{NADP}^{+}$by cell-free extracts (Martinez de Drets \& Arias, 1970). Excess isomerase and glucose-6-phosphate dehydrogenase (1 unit each) were added to the kinase assays to ensure maximum activity. Mannitol dehydrogenase (EC 1.1.1.14; L-iditol: $\mathrm{NAD}^{+}$2-oxidoreductase) was determined by measuring the reduction of $\mathrm{NAD}^{+}$(Leissing \& McGuinness, 1982). Controls without substrate were run with each assay.

\section{RESULTS AND DISCUSSION}

\section{Growth characteristics of BAL strains}

The wild-type $R$. leguminosarum biovar trifolii BAL is a highly efficient and effective nodulating strain which forms double infection threads (F. B. Dazzo, personal communication). However, this strain appears to grow more slowly than others on fructose. The ability of strain BAL to grow efficiently on mannitol and sucrose (Table 2) indicated that internal fructose was metabolized. It was found that the enzyme fructokinase, necessary to initiate metabolism of fructose, was functional (Table 3). This strain is still able to form effective nodules on clover (Dazzo \& Hubbell, 1975), which is consistent with data obtained from other fructose negative mutants of Rhizobium (Ronson \& Primrose, 1979).

BAL 79 is a Tn5 generated mutant of BAL which was unable to grow on mannitol or fructose, and showed impaired growth on sucrose (Table 2); it appeared to nodulate normally. This phenotype has also been described for a fructokinase negative mutant of $R$. leguminosarum

Table 2. Carbohydrate utilization by R. leguminosarum biovar trifolii BAL

\begin{tabular}{lcccc} 
& \multicolumn{4}{c}{ Growth on RDM medium with: } \\
\cline { 2 - 5 } Strain & Glucose & Sucrose & Fructose & Mannitol \\
BAL & + & + & slow & + \\
BAL 79 & + & slow & - & - \\
BAL C79 & + & + & slow & + \\
& &,+ Growth; - , no growth.
\end{tabular}

Table 3. Specific activities of fructokinase and mannitol dehydrogenase in $R$. leguminosarum biovar trifolii BAL strains

Specific activities are expressed as $\mu \mathrm{mol}$ NADPH or NADH produced $\min ^{-1}$ (mg protein) ${ }^{-1}$. Each value is the mean of six assays from duplicate cultures.

\begin{tabular}{|c|c|c|c|c|c|}
\hline \multirow[b]{2}{*}{ Enzyme } & \multirow[b]{2}{*}{ Strain } & \multicolumn{4}{|c|}{ Culture medium: } \\
\hline & & RDM-glycerol & RDM-glucose & $\begin{array}{l}\text { RDM-glycerol/ } \\
\text { mannitol }\end{array}$ & YEM \\
\hline Fructokinase & $\begin{array}{l}\text { BAL } \\
\text { BAL } 79 \\
\text { BAL C79 }\end{array}$ & $\begin{array}{l}0.061 \\
0.021 \\
0.256\end{array}$ & $\begin{array}{l}0.049 \\
0.020 \\
0.313\end{array}$ & $\begin{array}{l}0.172 \\
0.036 \\
0.196\end{array}$ & $\begin{array}{l}0.085 \\
0.023 \\
0.837\end{array}$ \\
\hline $\begin{array}{l}\text { Mannitol } \\
\text { dehydrogenase }\end{array}$ & $\begin{array}{l}\text { BAL } \\
\text { BAL } 79 \\
\text { BAL C79 }\end{array}$ & $\begin{array}{c}0.002 \\
\text { ND } \\
0.004\end{array}$ & $\begin{array}{l}0.002 \\
0.004 \\
0.004\end{array}$ & $\begin{array}{l}0.080 \\
0.083 \\
0.073\end{array}$ & $\begin{array}{l}0.038 \\
0.019 \\
0.028\end{array}$ \\
\hline
\end{tabular}

ND, None detected. 


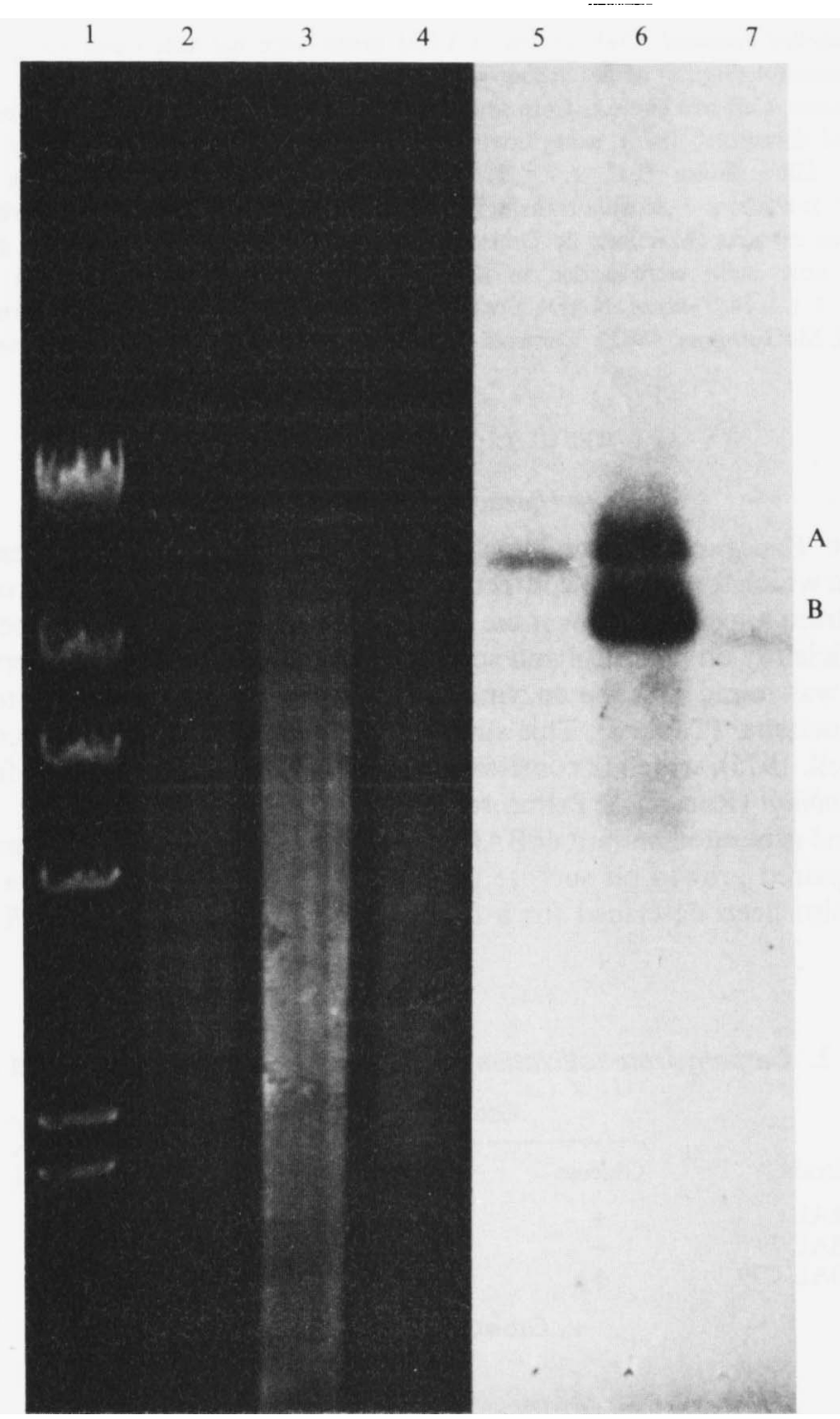

Fig. 1. Southern hybridization analysis of EcoRI digested DNA from BAL strains using Tn 5 with flanking regions as the probe. Lanes 1-4 represent digested DNA and lanes 5-7 represent the hybridization patterns. Lane $1, \lambda$-HindIII standard: lanes 2 and 5, BAL 79; lanes 3 and 6; BAL C79; lanes 4 and 7, BAL: A, Tn5-interrupted gene, B, intact gene.

(Glenn et al., 1984a). When grown on YEM medium, BAL 79 had a non-mucoid phenotype due to growth supported solely by yeast extract.

BAL C79 is a cosmid complemented derivative of BAL 79. This complementation allowed normal growth on all carbohydrates tested (Table 2), with increased production of fructokinase (Table 3). BAL C79 also appeared to nodulate normally.

\section{Isolation of the fructokinase mutant}

The introduction of $\mathrm{Tn} 5$ into BAL resulted in numerous kanamycin/streptomycin resistant colonies. Approximately 1000 of these colonies were replica plated onto RDM containing various single carbohydrates; the majority exhibited normal growth on all carbohydrates tested. 


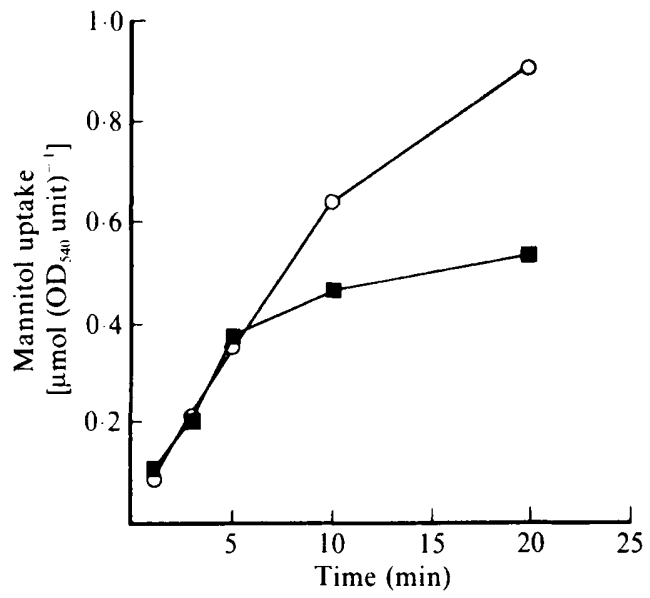

Fig. 2. Uptake of mannitol by strains BAL and BAL 79. Bacteria were grown in YEM and assayed as described in Methods. $\square$, BAL 79; O, BAL.

Of the colonies showing growth deficiencies, BAL 79, which was unable to grow on mannitol, was chosen for further study. Southern analysis verified that a single copy of $\operatorname{Tn} 5$ was present in the genome.

\section{Isolation and complementation of the fructokinase gene}

The fructokinase probe was obtained through EcoRI digestion of BAL 79 DNA. Since Tn5 contains no EcoRI sites, this allowed for the cloning of $\operatorname{Tn} 5$ with flanking regions of the inactivated gene.

One cosmid containing ten $E c o$ RI fragments was subcloned to yield a single EcoRI fragment. This fragment was used as a probe to isolate the intact fructokinase gene from a pLAFR 1 clone bank constructed from the BAL strain. One cosmid (pLA72) showing homology to the probe was used to complement BAL 79. Complementation was verified by the renewed ability to utilize mannitol and fructose, and the presence of pLA72. Southern hybridization analysis of the three BAL strains using the Tn 5 : : flanking DNA probe showed that BAL C79 contained two hybridizing bands (Fig. 1). One band corresponded to the inactive gene seen in BAL 79, and the other band corresponded to the active gene seen in BAL. The band representing the intact gene in BAL C79 had a greater intensity than the other band, presumably due to multiple copies of pLA72. BAL C79 retained the antibiotic markers of $\operatorname{Tn} 5$, indicating that the ability to utilize mannitol was not due to $\operatorname{Tn} 5$ excision.

\section{Enzyme analysis}

BAL strains were grown to mid-exponential phase in four different media (RDM supplemented with glycerol, glucose or glycerol/mannitol; and YEM) and assayed for intracellular glucokinase (not shown), frucktokinase and mannitol dehydrogenase (Table 3). The three strains had similar glucokinase activity (data not presented); however, levels of fructokinase differed dramatically. BAL 79 had a low level of fructokinase activity when grown in all media; this may have been due to non-specific glucokinase activity. The BAL and BAL C79 strains showed induction of fructokinase in the presence of mannitol, with BAL C79 showing approximately a sevenfold higher fructokinase level than BAL. Similarly, fructokinase activity was greater for BAL C79 when grown on the other media tested, ranging from three to ten times more. The increased enzyme production may be due to the presence of multiple plasmid copies, as suggested by the more intense hybridization band observed for BAL C79.

Mannitol dehydrogenase activity was measured to establish that internal fructose was available to cells (Table 3). Transport of $\left[{ }^{14} \mathrm{C}\right]$ mannitol was determined for BAL and BAL 79. Transport rates were similar for the two strains during the first $5 \mathrm{~min}$. Thereafter rates began to 
decrease for BAL 79 (Fig. 2), possibly due to high internal concentrations of fructose accumulated as a result of the fructokinase mutation in this strain. A fructokinase mutant of $R$. leguminosarum has been shown to accumulate levels of fructose to concentrations 300 -fold greater than external concentrations (Glenn et al., 1984a).

In summary, a $\operatorname{Tn} 5$ fructokinase negative mutant of $R$. leguminosarum biovar trifolii BAL was generated. This mutant (BAL 79) was identified by its low fructokinase activity and inability to utilize mannitol as a sole carbon/energy source. The ability of BAL 79 to transport mannitol and the presence of mannitol dehydrogenase further confirmed the location of the mutation. Complementation of the fructokinase mutation in BAL C79 was verified by the renewed utilization of mannitol and increased levels of fructokinase activity. The observed increase in fructokinase activity for BAL C79 was probably due to the presence of multiple plasmid copies. This increase in fructokinase activity does not appear to affect nodulation, probably due to rate limiting enzymes further in the metabolic pathway. Such a rate limiting effect makes it difficult to determine the benefits from multiple copies of metabolic genes.

\section{REFERENCES}

Arwas, R., MCKay, I. A., Rowney, F. R. P., Dilworth, M. J. \& GlenN, A. R. (1985). Properties of organic acid utilization mutants of Rhizobium leguminosarum strain 300. Journal of General Microbiology 131, 2059-2066.

BirNBoIM, H. C. \& DoLY, B. J. (1979). A rapid alkaline extraction procedure for screening recombinant plasmid DNA. Nucleic Acids Research 7, 1513-1523.

BRADFORD, M. (1976). A rapid and sensitive method for the quantitation of microgram quantities of protein utilizing the principle of protein-dye binding. Analytical Biochemistry 92, 248-254.

Chakrayorty, A. K., Zurkowski, W., Shine, J. \& ROLFE, B. G. (1982). Symbiotic nitrogen fixation: molecular cloning of Rhizobium genes involved in exopolysaccharide synthesis and effective nodulation. Journal of Molecular and Applied Genetics 1, 585-596.

Dazzo, F. B. \& Hubbell, D. H. (1975). Cross-reactive antigens and lectin as determinants of symbiotic specificity in the Rhizobium-clover association. Applied Microbiology 30, 1017-1033.

DunCan, M. (1981). Properties of Tn5 induced carbohydrate mutants of Rhizobium meliloti. Journal of General Microbiology 126, 237-241.

Friedman, A. M., Long, S. R., Brown, S. E., Buikema, W. J. \& Ausubel, F. M. (1982). Construction of a broad host range cloning vector and its use in the genetic analysis of Rhizobium japonicum. Gene 18, 289-296.

GlenN, A. R., ARwas, R., McKay, I. A. \& DILWORTH, M. J. (1984a). Fructose metabolism in wild-type, fructokinase-negative and revertant strains of Rhizobium leguminosarum. Journal of General Microbiology 130, 231-237.

Glenn, A. R., MCKay, I. A., ARWas, R. \& DilWORTH, M. J. (1984b). Sugar metabolism and symbiotic properties of carbohydrate mutants of Rhizobium leguminosarum. Journal of General Microbiology 130, 239-245.

Grunstein, M. \& Hogness, D. (1975). Colony hybridization: a method for the isolation of cloned DNAs that contain a specific gene. Proceedings of the National Academy of Sciences of the United States of America 72, 3961-3965.

HARDY, R. W. F. (1977). Rate-limiting steps in biological photoproductivity. In Genetic Engineering for Nitrogen Fixation, pp. 369-397. Edited by A. Hollaender. London: Plenum Press.

HoHN, B. \& Collins, J. (1980). A small cosmid for efficient cloning of large DNA fragments. Gene 11, 291-298.

LeIssing, N. \& McGuinness, E. T. (1982). Sorbitol dehydrogenase from rat liver. Methods in Enzymology 89, 135-140.

MaNiatis, T., Fritsch, E. F. \& SAMbroOK, J. (1982). Molecular Cloning: a Laboratory Manual. Cold Spring Harbor, NY: Cold Spring Harbor Laboratory.

MARTINez de Drets, G. \& Arias, A. (1970). Metabolism of some polyols by Rhizobium meliloti. Journal of Bacteriology 103, 97-103.

Pate, J. S. (1977). Functional biology of dinitrogen fixation by legumes. In $A$ Treatise on Dinitrogen Fixation, pp. 473-518. Edited by R. W. F. Hardy. New York: Wiley Interscience.

Ronson, C. W. \& Primrose, S. B. (1979). Carbohydrate metabolism in Rhizobium trifolii : identification and symbiotic properties of mutants. Journal of General Microbiology 112, 77-88.

Simon, R., Priefer, U. \& PUHLer, A. (1983). A broad host range mobilization system for in-vivo genetic engineering: transposon mutagenesis in gramnegative bacteria. BioTechnology 1, 784-791.

SOUTHERN, E. M. (1975). Detection of specific sequences among DNA fragments separated by gel electrophoresis. Journal of Molecular Biology 98, 503-517.

Sutton, B. C. S., Stanley, J., ZelechowsKa, M. G. \& Verma, D. S. (1984). Isolation and expression of Rhizobium japonicum cloned DNA encoding an early soybean nodulation function. Journal of Bacteriology 158, 920-927.

VINCENT, J. M. (1970). A Manual for the Practical Study of Root-nodule Bacteria (International Biological Programme Handbook no. 15). Oxford: Blackwell Scientific Publications.

Wahi, G. M., Ong, E., Meinkoth, J., Franco, R. \& BarinaGa, M. (1981). Methods for the Transfer of DNA, RNA and Protein to Nitrocellulose and Diazotized Paper Solid Supports. Dassel: Schleicher and Schuell Publishers. 